\title{
Gene-Drug Interaction in Stroke
}

\author{
Serena Amici, Maurizio Paciaroni, Giancarlo Agnelli, and Valeria Caso \\ Stroke Unit, Division of Cardiovascular Medicine, University of Perugia, Santa Maria della Misericordia Hospital, \\ Sant'Andrea delle Fratte, 06126 Perugia, Italy
}

Correspondence should be addressed to Serena Amici, samici@hotmail.com

Received 21 April 2011; Revised 5 July 2011; Accepted 2 September 2011

Academic Editor: Stephanie Debette

Copyright (c) 2011 Serena Amici et al. This is an open access article distributed under the Creative Commons Attribution License, which permits unrestricted use, distribution, and reproduction in any medium, provided the original work is properly cited.

\begin{abstract}
Stroke is the third cause of mortality and one of most frequent causes of long-term neurological disability, as well as a complex disease that results from the interaction of environmental and genetic factors. The focus on genetics has produced a large number of studies with the objective of revealing the genetic basis of cerebrovascular diseases. Furthermore, pharmacogenetic research has investigated the relation between genetic variability and drug effectiveness/toxicity. This review will examine the implications of pharmacogenetics of stroke; data on antihypertensives, statins, antiplatelets, anticoagulants, and recombinant tissue plasminogen activator will be illustrated. Several polymorphisms have been studied and some have been associated with positive drug-gene interaction on stroke, but the superiority of the genotype-guided approach over the clinical approach has not been proved yet; for this reason, it is not routinely recommended.
\end{abstract}

\section{Introduction}

Stroke is the third cause of mortality and one of most frequent causes of long-term neurological disability. Well-established risk factors for stroke include increasing age, hypertension, diabetes mellitus, cigarette smoking, obesity, heart disease, atrial fibrillation and sedentary $[1,2]$. However, a significant number of patients experience stroke in the absence of any risk factors; a hypothesis is that many risk factors have not been recognized yet, including genetic risk factors. The role of genetics has been evidenced through studies on twins and family history. Twin studies have shown that monozygotic twins are 1.6 more likely to be concordant for stroke than dizygotic twins [3]. Family history of stroke is a well-defined risk factor (OR 1.76 95\% CI 1.7-1.9) [3].

Given these data, genetic studies have increasingly been performed with the objective of revealing the genetic basis of cerebrovascular diseases. Genetic studies have been proposed to (1) reveal the pathogenetic basis of stroke, which might become a therapeutic target for new drugs, (2) optimize risk assessment, (3) identify populations requiring more aggressive therapeutic strategies, and (4) choose the optimal drug therapy by assessing the risk/benefit ratio based on genetic characteristics [4]. The latter application has been extensively studied in pharmacogenetic studies [5-7]. Recently, genetic studies have moved to "pharmacogenomic" that involve a genome-wide association approach which scans the entire genome looking through thousands of genetic variants; these hypothesis-free studies have the aim of discovering novel genes associated with a specific disease. This review has the aim of reporting on the latest developments regarding pharmacogenetics and pharmacogenomics of stroke, focusing on the most commonly used drugs in the acute phase, for primary and secondary prevention.

\section{Methods}

This review was planned using key words such as "pharmacogenetics" or "pharmacogenomics" and "stroke" to search literature. These words were combined with "antihypertensive agents," "statins," "hydroxymethylglutaryl-CoA Reductase Inhibitors," "tissue plasminogen activator," "anticoagulants," "vitamin K antagonist," "antiplatelets," "cyclooxygenase Inhibitors," "aspirin," "clopidogrel," and "acetil salicylic acid/ dipyridamole."

The following electronic databases were searched: MEDLINE (1995-June 11 2011) and EMBASE (1995-June 11 2011). One of the researchers (SA) read all the abstracts and 
selected all articles that included either "stroke" as outcome in primary prevention studies or as the target population in acute stroke treatment or secondary prevention studies. If any doubt was raised on an article's relevance, a second opinion was formulated by VC.

\section{Results}

In this section, pharmacogenetic studies involving drugs currently used for ischemic stroke (prevention or acute phase therapy) are reviewed.

3.1. Antihypertensive Agents. Hypertension is the most common stroke risk factor [41]. $\beta 1$ and $\beta 2$ adrenergic receptor (AR) plays a major role in cardiac disease; their codifying genes have been associated with response to antihypertensive drugs. $\beta 1-A R$ gene interacted with beta-blocker (BB) therapy. Stroke risk has been shown to be higher in rs\#2429511 carriers treated with BB (OR: 1.24, 95\% CI: 1.03-1.50). On the contrary, $\mathrm{BB}$ therapy did not interact with $\beta 2-A R$ gene variants on the risks of ischemic stroke (Table 1) [14]. A large randomised trial on treated hypertensive patients, enrolled to add either verapamil SR or trandolapril (International Verapamil SR-Trandolapril Study, INVEST study), focused on the genetic component of hypertension (INVEST-GENES) (Table 1) [8, 9, 17, 18, 20]. One of the papers derived from this study examined the polymorphism of $\alpha$-adducin (ADD1) Gly460Trp and race. The authors chose this polymorphism because $\alpha$-adducin, a cytoskeleton protein related with sodium sensitivity and diuretics efficacy, has been linked to essential hypertension [42]. The results did not evidence any diuretic-genotype interaction [20]. On the contrary, a population-based case control study on the same polymorphism found that diuretics protected ADD1 $460 \operatorname{Tr} p$ carriers from combined nonfatal $\mathrm{MI} /$ nonfatal stroke outcome. Other antihypertensive agents (e.g., beta blockers, ACE inhibitors, and calcium-channel blocker) did not show the same effect [19].

The randomised INVEST-GENES study also investigated the relation between subunit $\beta 1$ of the gene that encodes for a conductance calcium and voltage-dependent potassium channel (KCNMB1) genotype and response to calcium antagonists. The results showed that carriers of the Leu 110 polymorphism have a reduced risk of combined death, MI, and stroke when assuming verapamil SR to treat hypertension [9]. In addition, the same research group focused on G-protein-coupled receptor kinases (GRKs), receptors involved in beta-adrenergic signalling. GRK2 SNPs ( $r s 1894111 \mathrm{G}>\mathrm{A}$ ) and GRK5 Gln41Leu polymorphism were investigated in patients treated with atenolol or hydrochlorothiazide. The authors concluded that GRK $41 \mathrm{Leu}$ variant did not interact with any of the studied treatment regarding a combined cardiovascular outcome including death, MI, and stroke [8]. Finally, Pacawnosky investigated for an association between nitric oxide synthase (NOS 3) polymorphism [18], beta-adrenergic receptor gene $(A D R B 1$ and $A D R B 2)$ [17], and response to different antihypertensive agents. The first study focused on two NOS 3 polymorphisms since nitric oxide regulates vas- cular tone and is associated with many cardiac diseases [43]; no outcome or drug interaction was associated with genotype [18]. Also the second study did not evidence any genotype-drug interaction on stroke [17].

A population-based prospective cohort study focused on the renin-angiotensin system which is affected by ACE-inhibitors and BB (Table 1) $[15,16]$. Neither of the studies observed any interaction between drug use and genotype when stroke was considered as outcome $[15,16]$.

The genetics of hypertension-associated treatment (GenHAT) study investigated the ACE insertion/deletion (ACE $I / D)$ polymorphism in a large population of hypertensive patients with one or more cardiovascular risk factors. This randomised study did not report any association between treatment, genotype, and primary or secondary outcomes [11].

The same result was replicated in a more articulated investigation on the $A C E$ gene and 12 other polymorphisms (ADD1 Gly460Trp, $\beta 1 A R$ Gly389Arg, $\beta 2 A R$ Arg16Gly, $\beta 2 A R$ Gln27Glu, $\beta 3 A R$ Trp64Arg, AGT Met235Thr, Aldosterone synthase promoter C-344T, Type 1 angiotensinogen receptor A1166C, bradykinin 2 receptor $I / D, C Y P 2 C 9 * 2$ versus CYP2C9 * 1, CYP2C9 * 3 versus CYP2C9 * 1, G protein $\beta 3$-subunit C825T) [10]. This study was the product of the randomised LIFE (Losartan Intervention for Endpoint reduction in Hypertension) study trial, which included patients with hypertension and left ventricular hypertrophy treated with losartan versus atenolol. The authors did not evidence any genetic-drug interaction on different outcomes such as blood pressure and heart rate control, composite adverse cardiovascular outcome, cardiovascular death, MI, and stroke; in fact, they concluded that the clinical superiority of losartan in $25 \%$ stroke reduction compared to atenolol was not explained by these susceptibility genes [10].

A role in modulating antihypertensive agents has been suggested for the gene which codes for the precursor of atrial natriuretic polypeptide (NPPA gene). The polymorphism of this gene was studied by the GenHAT study [12]. The objective was to demonstrate that minor NPPA alleles in the T2238C or G664A variants had lower rates of primary outcome events compared with common allele homozygotes, if treated with diuretics. Subjects randomly receiving amlodipine, chlorthalidone, lisinopril, or doxazosin were included in a genetic for treatment interaction analysis. Carriers of the minor $C$ allele had more favourable stroke outcome when taking diuretics, whereas TT allele carriers had better stroke outcome when receiving a calcium channel blocker [12]. GenHAT [13] also showed that stroke risk was higher on lisinopril versus amlodipine in common GG homozygotes of fibrinogen beta $(F G B)$ gene, which codes for a polypeptide of the coagulation factor fibrinogen. On the contrary, variant $A$ allele carriers on lisinopril had slightly lower stroke risk. Finally, a pharmacogenetic study on perindopril failed to demonstrate a role for ACE I/D polymorphism on stroke [21].

3.2. Statins. The most currently used drugs for hypercholesterolemia are statins; although very effective, they induce a significant rate of adverse events such as myopathies and 
Table 1: Antihypertensive agents.

\begin{tabular}{|c|c|c|c|c|}
\hline Name & Outcome & Gene and variant & Sample size/drugs used & $\begin{array}{l}\text { Effect estimates and significance } \\
\text { levels }\end{array}$ \\
\hline $\begin{array}{l}\text { INVEST- } \\
\text { GENES } \\
{[8]}\end{array}$ & Death/MI or stroke & $\begin{array}{l}\text { GRK2 SNPs }(\text { rs1894111 } G>A) \\
\text { GRK5 Gln41Leu }\end{array}$ & $\begin{array}{l}\text { 48/Verapamil SR, } \\
\text { atenolol }\end{array}$ & $\begin{array}{l}\text { GRK5 } 41 \text { Leu decreased the risk of } \\
\text { adverse cardiovascular outcome } \\
\text { adjusted independently of treatment } \\
\text { (OR } 0.535,95 \% \text { CI: } 0.313-0.951 \text { ) }\end{array}$ \\
\hline $\begin{array}{l}\text { INVEST- } \\
\text { GENES } \\
{[9]}\end{array}$ & Death/MI or stroke & $\begin{array}{l}\text { KCNMB1 Glu65Lys } \\
\text { KCNMB1 Val110Leu }\end{array}$ & $\begin{array}{l}5979 \text { with } \\
\text { HTN/Verapamil SR, } \\
\text { atenolol }\end{array}$ & $\begin{array}{l}\text { KCNMB1 110Leu had reduced risk of } \\
\text { composite outcome (HR } 0.68 \text { ( } 95 \% \\
\text { CI } 0.47-0.998 \text { ); this effect was higher } \\
\text { in Verapamil SR (HR } 0.587,95 \% \text { CI } \\
0.33-1.04 \text { ) than atenolol-treated } \\
\text { patients (HR } 0.946,95 \% \text { CI } \\
0.56-1.59 \text { ) }\end{array}$ \\
\hline
\end{tabular}

\begin{tabular}{|c|c|c|c|c|}
\hline $\begin{array}{l}\text { LIFE } \\
\text { substudy } \\
{[10]}\end{array}$ & Cardiovascular events & $\begin{array}{l}13 \text { polymorphisms } \\
\text { (angiotensin-converting enzyme } \\
\text { I/D, } \alpha \text {-adducin Gly460Trp, } \\
\beta 1 \text {-adrenergic receptor } \\
\text { Gly389Arg, } \beta 2 \text {-adrenergic } \\
\text { receptor Arg16Gly, } \\
\beta 2 \text {-adrenergic receptor } \\
\text { Gln27Glu, } \beta 3 \text {-adrenergic } \\
\text { receptor Trp64Arg, } \\
\text { angiotensinogen Met235Thr, } \\
\text { aldosterone synthase promoter } \\
\text { C-344T, type } 1 \text { angiotensinogen } \\
\text { receptor A1166C, bradykinin } 2 \\
\text { receptor } \mathrm{I} / \mathrm{D}, \mathrm{CYP} 2 \mathrm{C} 9 * 2 \text { versus } \\
\text { CYP2C } * 1, \mathrm{CYP} 2 \mathrm{C} 9 * 3 \text { versus } \\
\text { CYP2C } * 1, \mathrm{G} \text { protein } \\
\beta 3 \text {-subunit C825T) }\end{array}$ & 3503/Losartan, atenolol & $\begin{array}{l}\text { No significant genotype-drug } \\
\text { interaction on the outcome }\end{array}$ \\
\hline $\begin{array}{l}\text { GEN-HAT } \\
{[11]}\end{array}$ & $\begin{array}{l}\text { Primary: fatal } \\
\text { CHD/nonfatal MI. } \\
\text { Secondary: stroke, } \\
\text { all-cause mortality, } \\
\text { combined CHD, and } \\
\text { combined } \\
\text { cardiovascular disease }\end{array}$ & ACE I/D & $\begin{array}{l}37,939 / \text { chlorthalidone, } \\
\text { amlodipine, lisinopril, } \\
\text { or doxazosin }\end{array}$ & $\begin{array}{l}\text { No significant association with the } \\
\text { outcome was reported; no significant } \\
\text { gene-drug interaction was found }\end{array}$ \\
\hline $\begin{array}{l}\text { GEN-HAT } \\
{[12]}\end{array}$ & $\begin{array}{l}\text { Primary: fatal } \\
\text { CHD/nonfatal MI. } \\
\text { Secondary: stroke, } \\
\text { all-cause mortality, } \\
\text { combined CHD, and } \\
\text { 6-mos systolic and } \\
\text { diastolic BP changes }\end{array}$ & $\begin{array}{l}\text { NPPA SNP T2238C (rs5065) } \\
\text { NPPA SNP G664A (rs5063) }\end{array}$ & $\begin{array}{l}38,462 \text { with } \\
\text { HTN/chlorthalidone, } \\
\text { amlodipine, lisinopril, } \\
\text { or doxazosin }\end{array}$ & $\begin{array}{l}\text { NPPA T2238C TT variant } \\
x \text { "chlorthalidone versus amlodipine" } \\
\text { interaction was significantly } \\
\text { associated stroke (HR } 1.0995 \% \text { CI } \\
0.95-1.26 \text { ). } \\
\text { NPPA T2238C TT variant } x \\
\text { "chlorthalidone versus amlodipine + } \\
\text { lisinopril" interaction was } \\
\text { significantly associated with stroke } \\
\text { (HR 1.09 95\% CI 0.95-1.26). } \\
\text { NPPA T2238C CC variant } x \\
\text { "chlorthalidone versus amlodipine" } \\
\text { interaction was significantly } \\
\text { associated with stroke (HR } 1.1895 \% \\
\text { CI 0.72-1.90). Either NPPA T2238C } \\
\text { variant or NPPA G664A was not } \\
\text { significantly associated with stroke } \\
\text { and "chlorthalidone versus } \\
\text { lisinopril," "chlorthalidone versus } \\
\text { doxazosin" }\end{array}$ \\
\hline
\end{tabular}


TABle 1: Continued.

\begin{tabular}{|c|c|c|c|c|}
\hline Name & Outcome & Gene and variant & Sample size/drugs used & $\begin{array}{l}\text { Effect estimates and significance } \\
\text { levels }\end{array}$ \\
\hline $\begin{array}{l}\text { GEN-HAT } \\
{[13]}\end{array}$ & $\begin{array}{l}\text { Primary: fatal } \\
\text { CHD/nonfatal MI. } \\
\text { Secondary: stroke, } \\
\text { heart failure, all-cause } \\
\text { mortality, end-stage } \\
\text { renal disease }\end{array}$ & FGB G455A & $\begin{array}{l}30076 \text { with } \\
\text { HTN/chlorthalidone, } \\
\text { amlodipine, lisinopril }\end{array}$ & $\begin{array}{l}\text { Common GG homozygotes had } \\
\text { higher stroke risk on lisinopril versus } \\
\text { amlodipine (HR } 1.38, P<0.001) \text {; } \\
\text { variant A allele carriers had slightly } \\
\text { lower risk on lisinopril versus } \\
\text { amlodipine (HR } 0.96, P \text { value for } \\
\text { interaction }=0.03 \text { ) }\end{array}$ \\
\hline $\begin{array}{l}\text { Lemaitre } \\
\text { et al. [14] }\end{array}$ & MI, ischemic stroke & $\begin{array}{l}\text { ADRB1 (Seven SNPs plus } \\
\text { haplotype), ADRB2 (five SNPs } \\
\text { plus haplotypes) }\end{array}$ & $\begin{array}{l}938 \text { cases with MI or } \\
\text { stroke/beta blocker }\end{array}$ & $\begin{array}{l}\text { betal-AR gene variation and } \\
\text { beta-blocker use showed a positive } \\
\text { interaction on ischemic stroke risk } \\
(P=0.04) \text {. Homozygosis or } \\
\text { heterozygosis for rs } 2429511 \text { variant } \\
\text { was associated with higher MI/stroke } \\
\text { combined risk in beta-blocker users } \\
\text { (OR } 1.2495 \% \text { CI } 1.03-1.50) \text {. } \\
\text { No interaction of ADRB2 with } \\
\text { beta-blocker use and outcomes }\end{array}$ \\
\hline $\begin{array}{l}\text { Rotterdam } \\
\text { study [15] }\end{array}$ & MI, stroke & AGT (M235T) & $\begin{array}{l}4097 \text { with HTN/ACEI, } \\
\text { BB }\end{array}$ & $\begin{array}{l}\text { No significant gene-drug interaction } \\
\text { was found on stroke }\end{array}$ \\
\hline $\begin{array}{l}\text { Rotterdam } \\
\text { study [16] }\end{array}$ & MI, stroke & $\begin{array}{l}\text { AGTR1 (C573T) } \\
\text { ACE (I/D) }\end{array}$ & $\begin{array}{l}4097 \text { with } \mathrm{HTN} / \mathrm{ACEI}, \\
\mathrm{BB}\end{array}$ & $\begin{array}{l}\text { No significant AGTR1 and ACE I/D } \\
\text { interaction on stroke risk with ACEI } \\
\text { or BB }\end{array}$ \\
\hline $\begin{array}{l}\text { INVEST- } \\
\text { GENES } \\
{[17]} \\
\end{array}$ & $\begin{array}{l}\text { Death/nonfatal } \\
\text { MI/nonfatal stroke }\end{array}$ & $\begin{array}{l}\text { ADRB1 (Ser49GLy, Arg389Gly) } \\
\text { and ADRB2 (Gly16Arg, } \\
\text { Gln27Glu, 523 C > A) }\end{array}$ & $\begin{array}{l}5,895 \mathrm{CAD} \\
\text { patients/Verapamil SR, } \\
\text { atenolol }\end{array}$ & $\begin{array}{l}\text { No association between any } \\
\text { haplotype and treatment on stroke }\end{array}$ \\
\hline $\begin{array}{l}\text { INVEST- } \\
\text { GENES } \\
{[18]}\end{array}$ & $\begin{array}{l}\text { Death/nonfatal } \\
\text { MI/nonfatal stroke }\end{array}$ & $\begin{array}{l}\text { NOS3-786T > C (rs2070744), } \\
\text { NOS3 Glu298 > Asp (rs1799983) }\end{array}$ & $\begin{array}{l}258 \text { death/MI/stroke } \\
\text { versus } 774 \text { control }\end{array}$ & $\begin{array}{l}\text { No genetic interaction with drugs } \\
\text { and composite outcome }\end{array}$ \\
\hline $\begin{array}{l}\text { Psaty et al. } \\
{[19]}\end{array}$ & MI/nonfatal stroke & ADD1 (Gly460Trp) & Cases versus controls & $\begin{array}{l}\text { ADD1 Trp460 variant had lower } \\
\text { stroke risk on diuretics (OR, } 0.49 \text {; } \\
95 \% \text { CI, 0.32-0.77). The point } \\
\text { estimate of diuretic-adducin } \\
\text { interaction was SI } 0.45 \text { ( } 95 \% \text { CI } \\
0.26-0.79 \text { ) for the combined } \\
\text { outcome MI and stroke; separate } \\
\text { analyses yielded similar results: MI } \\
\text { (SI } 0.4195 \% \text { CI } 0.21-0.80 \text { ) and } \\
\text { stroke (SI } 0.5395 \% \text { CI } 0.24-1.19 \text { ) }\end{array}$ \\
\hline $\begin{array}{l}\text { INVEST- } \\
\text { GENES } \\
{[20]}\end{array}$ & $\begin{array}{l}\text { Death/nonfatal } \\
\text { MI/nonfatal stroke }\end{array}$ & ADD1 Gly460Trp & $\begin{array}{l}5,979 \mathrm{CAD} \\
\text { patients/Verapamil SR, } \\
\text { atenolol }\end{array}$ & $\begin{array}{l}\text { ADD1 Trp } 460 \text { black carriers had } \\
\text { higher combined outcome risk (aHR } \\
2.62,95 \% \text { CI } 1.23-5.58) \text {, compared } \\
\text { to whites (aHR } 1.2495 \% \text { CI } \\
0.90-1.71 \text { ) and Hispanics (aHR } 1.43 \\
95 \% \text { CI } 0.86-2.39 \text { ). No significant } \\
\text { interaction between the ADD1 } \\
\text { polymorphism and diuretic use for } \\
\text { either primary outcome or secondary } \\
\text { outcomes }\end{array}$ \\
\hline
\end{tabular}


Table 1: Continued.

\begin{tabular}{|c|c|c|c|c|}
\hline Name & Outcome & Gene and variant & Sample size/drugs used & $\begin{array}{l}\text { Effect estimates and significance } \\
\text { levels }\end{array}$ \\
\hline $\begin{array}{l}\text { PROGRESS } \\
{[21]}\end{array}$ & $\begin{array}{l}\text { Fatal and nonfatal } \\
\text { stroke (ischemic or } \\
\text { hemorrhagic), } \\
\text { nonfatal MI/coronary } \\
\text { death, composite } \\
\text { nonfatal } \\
\text { stroke/nonfatal } \\
\text { MI/vascular death, } \\
\text { all-cause mortality, } \\
\text { dementia, and } \\
\text { cognitive decline }\end{array}$ & ACE I/D & $\begin{array}{l}5688 \text { with stroke or } \\
\text { TIA/perindopril }\end{array}$ & $\begin{array}{l}\text { No associations between ACE } \\
\text { genotypes and cerebrovascular } \\
\text { disease history or cardiovascular risk } \\
\text { factors was demonstrated. The ACE } \\
\text { genotype was not associated with the } \\
\text { long-term risks of stroke. The ACE } \\
\text { genotype did not modify the relative } \\
\text { benefits of perindopril over placebo }\end{array}$ \\
\hline
\end{tabular}

abnormal transaminase levels. Recent pharmacogenetics data has contributed to better understanding statin pharmacokinetics and pharmacodynamic variability [44]. Pharmacogenetic and dynamic properties have been extensively studied, but only few studies included stroke as outcome (Table 2) [22-25].

A population-based cohort study focused on apolipoprotein E, a protein involved in lipid clearance rate and conversion together with the production of triglycerides and very low-density lipoprotein. The Apo E gene encodes for three alleles: E2, E3, and E4 [45]. The results did not show genestatin interaction with stroke; stroke risk was reduced independently of Apo E genotype in statin users [24]. The same author examined the effect of $A C E I / D$ polymorphism on stroke using the Gen-HAT data. None of the outcomes evidenced significant ACE I/D-pravastatin interaction [25]. The randomised heart protection study focused on Kinesin family member 6 (KIF) gene, whose variant has been associated with reduced coronary events [46]. The authors did not find any significant interaction between the studied polymorphism KIF Trp719Arg and simvastatin use for any of the outcomes, including stroke [23]. The only study that yielded positive results was a case-control study that involved patient with MI and stroke. The authors focused on six genes that have been associated to statin treatment response: ATP-binding cassette subfamily $\mathrm{B}(A B C B 1)$ gene that encodes for a drug transporter involved in statins metabolism; CETP, human hepatic lipase gene (LIPC) and low density lipoprotein receptor $(L D L R)$, genes related to lipid metabolism; $H M G C R$, the target protein of statins; NOS3, a key gene implicated in maintaining the endothelium, which in turn mediates several effects of statins [22]. The authors found 5 polymorphisms (one in CETP and 1 in LIPC) that had significant interactions with statins on stroke outcome [22], the highest significance level was found in the CETP SNPs (rs5883), which was associated with stroke risk in simvastatin users. No gene level interactions were found for stroke [22].

3.3. Tissue Plasminogen Activator. Recombinant tissue plasminogen activator (rTPA) is the only licensed drug to treat ischemic stroke in the acute phase (within 3-4.5 hours from onset). This drug is administered to treat ischemic stroke and restore blood flow to the brain $[47,48]$. The clinical benefit of rTPA is counterbalanced by a higher risk of hemorrhagic complications; $2-10 \%$ of patients develops symptomatic hemorrhagic transformations and $40 \%$ asymptomatic hemorrhagic events [49-51]. The functional role of rt-PA is to convert plasminogen into plasmin, which has fibrinolytic activity. The higher activity of the enzyme produces hyperfibrinolysis and consequently bleeding, whereas lower activity causes hypofibrinolysis and, as a consequence, thrombosis or embolism [52]. Genetic association studies have sought to investigate genetic profiles correlated with clinical and pathophysiological rt-PA response (Table 3). Broderick et al. $[26,53]$ examined the role of the $A p o E$ phenotypes and reported that rt-PA efficacy was greater in acute stroke patients with an ApoE E2 phenotype (OR: 6.4; 95\%, CI: 2.715.3), whereas the outcome of placebo-treated patients with or without Apo E E2 did not differ [26]. Conversely, a Spanish group did not report on any association with Apo E genotype and hemorrhagic risk and recanalisation rate after thrombolytic treatment [27]. The same group explored the hypothesis that matrix metalloproteinase-9 gene (MMP-9), which codes for proteins associated with blood-brain barrier disruption, was associated with hemorrhagic transformation in rTPA-treated patients. However, the authors did not find any association between a MMP-9 C-1562T common polymorphism and hemorrhagic risk [32]. On the other hand, the authors reported that thrombolytic intervention yielded middle cerebral artery (MCA) recanalisation associated with DD homozygosis of ACE I/D polymorphism; this has been linked to procoagulant factors including PAI-1, fibrinogen's levels as well as Factors VII and X activities [29]. Another study of the same group has identified V34L factor XII polymorphism as a predictor of outcome with rTPA treatment; good outcome was associated with $V V$ genotype and low fibrinogen levels, while a higher risk of inefficacy of thrombolytic therapy and mortality was found with L34 genotype and high fibrinogen levels [31]. In addition, FernandezCadenas and colleagues studied the influence of two genes coding for fibrinolysis inhibitors, thrombin-activatable fibrinolysis inhibitor (TAFI), and plasminogen activator inhibitor-1 (PAI-1) genes. They demonstrated that TAFI Thr325Ile polymorphism predicted the absence of recanalisation with 
TABLE 2: Statins.

\begin{tabular}{l}
$\begin{array}{l}\text { Author's } \\
\text { name/study } \\
\text { name }\end{array}$ \\
\hline
\end{tabular}

name

$\begin{array}{lll} & \\ \text { Hindorff et al. } & \begin{array}{l}\text { Nonfatal MI/nonfatal } \\ \text { stroke }\end{array} & \begin{array}{l}\text { ABCB1, CETP, HMGCR, } \\ \text { L22] }\end{array}\end{array}$

\begin{tabular}{|c|c|c|c|}
\hline $\begin{array}{l}\text { Hindorff et al. } \\
{[22]}\end{array}$ & $\begin{array}{l}\text { Nonfatal MI/nonfatal } \\
\text { stroke }\end{array}$ & $\begin{array}{l}\text { ABCB1, CETP, HMGCR, } \\
\text { LDLR, LIPC, NOS3 }\end{array}$ & $\begin{array}{l}\text { stroke and } 2686 \\
\text { controls/statins }\end{array}$ \\
\hline
\end{tabular}
No gene-statin interactions for stroke.
5 SNP-statin interactions on stroke (one CETP, four LIPC); no gene level association for stroke; SNP level association: two SNPs (one CETP, one LDLR) for stroke. The highest significance was found for stroke in CETP rs5883 carriers on simvastatin (OR 3.60 95\% CI 1.22-7.70)

\begin{tabular}{|c|c|c|c|c|}
\hline $\begin{array}{l}\text { Heart } \\
\text { protection } \\
\text { study [23] }\end{array}$ & $\begin{array}{l}\text { Major coronary event } \\
\text { (coronary death or nonfatal } \\
\text { MI), major vascular event } \\
\text { (major coronary event plus } \\
\text { revascularization or stroke) }\end{array}$ & $\begin{array}{l}\text { KIF6 Trp719Arg } \\
\text { polymorphism (rs20455) } \\
\text { on vascular risk and } \\
\text { response to statin therapy } \\
\text { in from of the heart } \\
\text { protection study }\end{array}$ & $\begin{array}{l}18,348 \\
\text { participants/simvastatin }\end{array}$ & $\begin{array}{l}\text { No significant gene-statin } \\
\text { interaction with any of the } \\
\text { outcome, including stroke }\end{array}$ \\
\hline $\begin{array}{l}\text { Rotterdam } \\
\text { study [24] }\end{array}$ & Death, MI, stroke & Apo E (E2, E3, E4) & $\begin{array}{l}7983 \text { older than } 55 \\
\text { yo/statins }\end{array}$ & $\begin{array}{l}\text { No significant gene-statin } \\
\text { interaction with any of the } \\
\text { outcome. } \\
\text { Statins reduce stroke risk } \\
\text { (aOR } 0.5095 \% \text { CI } 0.28-0.91 \text { ) } \\
\text { independently of Apo E } \\
\text { genotype }\end{array}$ \\
\hline GenHAT [25] & $\begin{array}{l}\text { Primary outcome: all-cause } \\
\text { mortality, secondary } \\
\text { outcomes (fatal CHD and } \\
\text { nonfatal MI, CVD } \\
\text { mortality, CHD, stroke, } \\
\text { other CVD, non-CVD } \\
\text { mortality, stroke, and heart } \\
\text { failure) }\end{array}$ & $\mathrm{ACE}(\mathrm{I} / \mathrm{D})$ & 9467/pravastatin & $\begin{array}{l}\text { No significant gene-statin } \\
\text { interaction with any of the } \\
\text { outcome }\end{array}$ \\
\hline
\end{tabular}

t-PA infusion. On the contrary, PAI-1 4 G/5 G polymorphism did not influence recanalisation rate. However, the combination of these two polymorphisms doubled the risk of negative response to therapy [30]. A recent study using a candidate gene approach has explored the association of 263 SNPs and recanalisation rate in TPA-treated patients; cluster of differentiation 40 (CD40) $1 \mathrm{C}>\mathrm{T}$ and matrix Gla protein (MGP)-7A > G polymorphism were both associated with reocclusion although only the latter was associated with neurological worsening at $24 \mathrm{~h} \mathrm{[28].} \mathrm{This} \mathrm{may} \mathrm{be} \mathrm{due} \mathrm{to} \mathrm{the}$ role of CD40 in thrombosis and inflammation [54], while MGP gene might have a protective role in atherosclerosis [55]. To date, GWAs has not been performed on human subjects.

3.4. Anticoagulants. Anticoagulation is first-line treatment for cardioembolic stroke. Although these drugs are effective in almost $60 \%$ of cases, the hemorrhagic risk is double and even higher in the first period of therapy [1]. Recent acquisition on pharmacogenetics of warfarin has been suggested to be able to predict the optimal initial dosage of warfarin using a genotype-guided approach (Table 4). This approach promises to adequately prevent stroke and to minimize hemorrhagic risk. Several candidate gene studies have mainly focused on cytochrome P450 (CYP) and vitamin K epoxide reductase complex subunit 1 (VKORC1) $[56,57]$. Cytocrome P 450 metabolises in the liver S-warfarin by CYP2C9 and R-warfarin by the CYP1A1, CYP1A2, and CYP3A4; these enzymes affect warfarin kinetics, and several SNPs of CYP450 have been correlated with its sensitivity [58]. The VKORC1 enzyme converts the epoxide into reduced vitamin K; however warfarin inhibits this reaction. As a consequence, the physiologic role of vitamin $\mathrm{K}$, which produces $\gamma$-carboxylation of several coagulation factors (prothrombin, factor VII, IX, and X), is inhibited.

Several groups have studied the role of VKORC1 in warfarin/acenocoumarol dose finding, dose maintenance, and bleeding risk associated with these drugs [33, 34, 59-61]. Only two studies have focused on patients receiving vitamin 
TABle 3: Tissue plasminogen activator.

\begin{tabular}{|c|c|c|c|c|}
\hline $\begin{array}{l}\text { Author's name/study } \\
\text { name }\end{array}$ & Outcome & Gene (Variant) & Sample Size/drug & Effect estimates and findings \\
\hline $\begin{array}{l}\text { Broderick et al. } \\
2001[26]\end{array}$ & $\begin{array}{l}\text { Favourable outcome (NIHSS of } \\
0 \text { or } 1 \text {, Barthel Index of } 95 \text { or } \\
100 \text {, Modified Rankin Scale of } 0 \\
\text { or } 1 \text {, and a Glasgow Outcome } \\
\text { Scale of } 1 . \text { ) }\end{array}$ & ApoE (E2, E3, E4) & $\begin{array}{l}409 \text { ischemic } \\
\text { stroke/rTPA versus } \\
\text { PB within } 3 \text { hours }\end{array}$ & $\begin{array}{l}\text { ApoE E2 phenotype-rt-PA interaction } \\
\text { was associated with good outcome at } 3 \\
\text { months (OR: } 6.4 ; 95 \% \text { CI: } 2.7-15.3 \text { ). } \\
\text { Apo E4 phenotype not related to } \\
\text { favorable } 3 \text { month outcome, response } \\
\text { to t-PA, 3-month mortality, or risk of } \\
\text { intracerebral hemorrhage }\end{array}$ \\
\hline $\begin{array}{l}\text { Fernández-Cadenas } \\
\text { et al. [27] }\end{array}$ & $\begin{array}{l}\text { Recanalization rate, NIHSS at } \\
48 \text { hours and mRS score at } 3 \\
\text { months, heamorrhagic } \\
\text { transformation }\end{array}$ & ApoE (E2, E3, E4) & $\begin{array}{l}77 \text { ischemic } \\
\text { stroke/rTPA } \\
\text { within } 3 \text { hours }\end{array}$ & $\begin{array}{l}\text { No significant association of ApoE } \\
\text { genotype and the studied outcome }\end{array}$ \\
\hline $\begin{array}{l}\text { Del Río Espínola } \\
\text { et al. [28] }\end{array}$ & Reocclusion rate & $\begin{array}{l}236 \text { SNPs form } \\
\text { candidate genes for } \\
\text { vascular risk factor }\end{array}$ & $\begin{array}{l}222 \text { ischemic } \\
\text { stroke/rTPA }\end{array}$ & $\begin{array}{l}\text { rs1883832 SNP from CD40 gene (OR: } \\
0.077 ; 95 \% \text { CI: } 0.009-0.66) \text { and } \\
\text { rs1800801 SNP from the MGP gene } \\
\text { (OR 15.25; 95\% CI: } 2.23-104.46) \text { were } \\
\text { independently associated with } \\
\text { reocclusion after adjustment for } \\
\text { clinical predictors }\end{array}$ \\
\hline $\begin{array}{l}\text { Fernández-Cadenas } \\
\text { et al. [29] }\end{array}$ & Recanalization & $\mathrm{ACE}(\mathrm{I} / \mathrm{D})$ & $\begin{array}{l}96 \text { ischemic } \\
\text { stroke/rTPA } \\
\text { within } 3 \text { hours }\end{array}$ & $\begin{array}{l}\text { ACE DD homozygosis was } \\
\text { significantly associated with } \\
\text { recanalization rate following rTPA } \\
\text { (OR: } 4.395 \% \text { CI: } 1.35-13.49 \text { ). } \\
\text { No relation was found between ACE } \\
\text { I/D polymorphism and symptomatic } \\
\text { hemorrhagic complications. No } \\
\text { association between ACE genotypes } \\
\text { and Factor VII or Factor X activities }\end{array}$ \\
\hline
\end{tabular}

PAI-1 4 G/5 $G$ was not associated with recanalization.

TAFI Thr325Ile polymorphism was

\begin{tabular}{|c|c|c|c|}
\hline $\begin{array}{l}\text { Fernández-Cadenas } \\
\text { et al. [30] }\end{array}$ & Recanalization & $\begin{array}{l}\text { PAI-1 4G/5G } \\
\text { TAFI (Thr325Ile) }\end{array}$ & $\begin{array}{l}139 \text { with ischemic } \\
\text { stroke/TPA within } 3 \\
\text { hours }\end{array}$ \\
\hline
\end{tabular}
associated with recanalization resistance (OR 5.6 95\% CI 1.2-20). Combination of TAFI and PAI-1 polymorphisms double the risk of absence of recanalization (OR: 11.1; 95\% CI: $1.4-89.8)$

FXIII $34 \mathrm{~L}$ carriers had higher death risk than V/V (OR $2.5095 \% \mathrm{CI}$ 1.00-7.06); high fibrinogen levels
higher risk than lower levels (OR 2.72

González-Conejero Death, recanalization et al. [31] Factor XIII (FXIII)
V34L
200 with ischemic stroke/TPA within 3 hours
95\% CI 1.01-7.44); FXIII 34L and high fibrinogen level higher risk than FXII V and low fibrinogen (OR 5.74 95\% CI 1.51-11.56).

No difference in recanalization rate

61 with ischemic stroke/TPA within 3 hours
The polymorphism studied does not increase hemorrhagic risk
$\mathrm{K}$ antagonist following cardioembolic stroke. One found that the time and cumulative dosage of phenprocoumon needed to achieve target 2-3 INR ratio were associated with the presence of the VKORC1 C283 + C837T ( rs2359612) polymorphism. Carriers of TT genotype needed shorter time to achieve target INR ratio (3.2 days) compared to $C C$ carriers (6.5 days) [33]. The second paper evaluated the roles of VKORC1, gamma-glutamyl carboxylase (GGCX), calumenin (CALU), and cytochrome P450 2C9 (CYP2C9) in warfarin maintenance dose on Japanese stroke sufferers. Of the twelve 
TABLE 4: Anticoagulants and antiplatelets.

\begin{tabular}{l}
$\begin{array}{l}\text { Author's name/study } \\
\text { name }\end{array}$ \\
\hline
\end{tabular}

Anticoagulants

Arnold et al. [33] Dose finding VKORC1 C283 +837C $\rightarrow \quad 49$ with cerebrovascular $\mathrm{T}(\mathrm{rs} 2359612) \quad$ disease/phenprocoumon

VKORC1 TT carriers reached an INR of 2-3 after a mean time of 3.2 days $(n=5)$, CT carriers after 4.4 days $(n=27)$, and CC carriers after 6.5 days $(n=15)$

(VKORC1), gamma-glutamyl

Kimura et al. [34] Warfarin maintenance dose carboxylase (GGCX), calumenin (CALU), and cytochrome P450 2C9 (CYP2C9)
93 Japanese on stable anticoagulation therapy
$1639 G>A(P=0.004)$ and $3730 G>A$ genotypes $(P=0.006)$ in VKORC1, the $8016 G>A$ genotype in GGCX

$(P=0.022)$, and the $42613 A>C$ genotype in CYP2C9 $(P=0.015)$ were associated with effective warfarin dose

\section{Antiplatelets}

Meta-analysis of 9 different studies

(CLARITY TIMI 28, EXCLESIOR, TRITION TIMI 38, AFIJI, FASSTS-MI, RECLOSE, ISAR, CLEAR PLATELETS,

Composite outcome (cardiovascular death/MI/stroke) and stent thrombosis
CYP2C19/1 or 2 reduced function alleles $(* 2, * 3$, $* 4, * 5, * 6, * 7$, and $* 8$ )
9685 patients $(91 \%$ had PCI, 54\% had ACS)/clopidogrel
Carriers of 1 (HR 1.55; 95\% CI, $1.11-2.17$ ) or 2 (HR $1.76 ; 95 \%$ CI, 1.24-2.50) reduced-function CYP2C19 alleles had higher risk of composite outcome events
TRITON-TIMI 38 [36]
Composite outcome (cardiovascular death/MI/ischemic stroke)
CYP2C19/1 or 2 reduced function alleles $(* 2, * 3$, $* 4, * 5, * 6, * 7$, and $* 8$ ) $\mathrm{ABCB} 1 / 3435 \mathrm{C} \rightarrow \mathrm{T}$
2932 patients with ACS undergoing PCI/clopidogrel versus prasugrel
TT homozygotes of ABCB1 genotype had increased risk of the composite outcome compared to CT or CC carriers (HR 1.72, 95\% CI 1.22-2.44). Carriers of a CYP2C19 reduced-function allele only (Kaplan-Meier event rate 11.5\%), ABCB1 3435 TT homozygotes only (Kaplan-Meier event rate $12.6 \%$ ), or both (Kaplan-Meier event rate $13.6 \%$ ) had increased risk of composite outcome (pooled HR 1.97, 95\% CI 1.38-2.82).

No significant genotype-prasugrel interaction was reported 
Table 4: Continued.

\begin{tabular}{l}
$\begin{array}{l}\text { Author's name/study } \\
\text { name }\end{array}$ \\
\hline
\end{tabular}

name

PLATO [37] $\quad \begin{array}{ll}\text { Composite outcome } \\ \text { (cardiovascular } \\ \text { death/MI/stroke) }\end{array} \quad \begin{aligned} & \text { CYP2C19/1 or } 2 \text { reduced } \\ & \text { function alleles } \\ & \text { ABCB1/3435C } \rightarrow \mathrm{T}\end{aligned}$
Mount Sinai study [38]

Clappers et al. [39] $\begin{aligned} & \text { (cardiovascular } \\ & \text { death/MI/stroke) }\end{aligned}$

Composite outcome (cardiovascular death, MI, ischemic stroke, stent thrombosis, unplanned target vessel revascularization,

GWA unplanned nontarget vessel revascularization, hospitalization for coronary ischemia)

Composite outcome death/MI/stroke)
10285 patients with ACS undergoing non-CABG/clopidogrel versus ticagrelor
Either with (HR 0.77, 95\% CI $0.60-0.99)$ and without $(0.86$, $0.74-1.01, P=0.0608$ ) any CYP2C19 reduced-function alleles patients on ticagrelor experienced lower risk of composite outcome compared to patients on clopidogrel (interaction $P=0.46$ ). Independently of $\mathrm{ABCB} 1$ genotype, patients on ticagrelor had lower risk of the composite outcome compared to clopidogrel users (interaction $P=0.39$; HR $0.71,95 \%$ CI $0.55-0.92$ ).

No significant interaction was found on treatment and genotype regarding major bleeding

13 SNPs in 10q24 region, where CYP2C18-CYP2C19-CYP2C9CYP2C8 gene cluster is found, 429 white healthy Amish individuals/clopidogrel; results replicated in 227 undergoing PCI were associated with reduced response to clopidogrel. CYP2C19 $* 2$ allele carriers were at higher risk for composite outcome (adjusted HR 2.42 95\% CI 1.18-4.99)

\section{6 admitted to Coronary Care Unit for different reasons/aspirin \\ No interaction was found on genotype and aspirin for the composite outcome}

COX-1/C116T, del

137-142, C144T, G6841A, G7331C, A7742A, C10427A, C10608A, del

10675A, G12254A, T12378C, G19187A, C19242T, G19255A
14 variants of the Cox-1 gene were identified and 7 involved amino acid substitutions of the Cox-1 molecule. None of the mutations were located near the catalytic site

ABCB1: ATP-binding cassette subfamily B, ACEI: angiotensin convertin enzyme inhibitors, ACE I/D: angiotensin convertin enzyme insertion/deletion, ACS: acute coronary syndrome, ADD1: $\alpha$-adducin, ADRB: $\beta$-adrenergic receptor, AGT: angiotensinogen, AGTR1: angiotensin receptor II type 1, APO E: apolipoprotein E, BP: blood pressure, CABG: coronary artery bypass graft, CAD: coronary heart disease, CD: cluster of differentiation, CEPT: cholesteryl ester transfer protein, CHD: coronary artery disease, COX: cyclooxygenase, CVD: cerebrovascular disease, CYP: cytochrome P, FGB: fibrinogen beta, GRK: G-proteincoupled receptor kinase, GWA: genome-wide association, HMG-CoR: hydroxyl-methylcoenzyme A reductase, HR: hazard ratio, HTN: hypertension, KCNMB: conductance calcium and voltage-dependent potassium channel, KIN 6: kinesin family member 6, LDLR: low-density lipoprotein receptor, LIPC: human hepatic lipase, MGP: matrix Gla protein, MI: myocardial infarction, MMP: matrix metalloproteinase, NIHSS: National Institute of Health stroke scale, NOS: nitric oxide synthase, NPPA: atrial natriuetic polypeptide precursor, OR: odds ratio, PAI: plasminogen activator inhibitor, PCI: percutaneous coronary intervention, SI: sinergy index, TAFI: thrombin-activable fibrinolysis inhibitor, verapamil SR: verapamil-sustained release, VKORC1: vitamin K epoxide reductase complex subunit 1 . 
SNPs analysed, the authors found that the $1639 G>A, 3730 G$ $>A$ VKORC1 genotypes; the $8016 G>A$ GGCX genotype, and the $42613 A>C C Y P 2 C 9$ genotype were associated with dose maintenance. Thus, the variation in warfarin dose was explained for $33.3 \%$ by age, sex, weight, and three genetic polymorphisms (VKORC1-1639G > A, CYP2C9 42613A>C, GGCX $8016 G>A$ ). The importance of these loci has been recently confirmed using genome-wide association studies in acenocoumarol-treated patients $[62,63]$. These studies found that the SNPs with the highest significance level were located in chromosome (cr.) 16 (rs10871454 and rs9923231) linked to VKORC1 and cr. 10 (rs4086116 and rs105791) linked with CYP2C9 gene. After adjusting for these two SNPs, two other polymorphisms reached significant association with acenocoumarol: rs2108622 within CYP4F2 gene on cr.19 and rs1995891 within CYP2C18 on cr. $10[62,63]$.

3.5. Antiplatelets. Antiplatelet drugs are commonly used treatment for ischemic noncardioembolic stroke [1].

3.5.1. Aspirin. Aspirin is the more commonly used drug of this class, and its efficacy ranges between $13 \%$ and $25 \%$. Its physiological role is to acetylate serine residue 530 in the active site of cyclooxygenase-1 (COX-1), sterically inhibiting the metabolism of arachidonic acid and consequently reducing thromboxane $\mathrm{A} 2$ ( $\mathrm{TxB} 2)$, which activates platelets. Numerous studies have investigated the genetic basis associated with recurrence of ischemic event in aspirin-treated patients (e.g., aspirin failure) (Table 4).

COX-1 C50T allele has been correlated with a higher level of 11-dehydro-TxB2, both before and after aspirin; however, the haplotype studied did not confirm a genetic basis for aspirin failure $[64,65]$. In addition, this polymorphism is not associated with a higher risk of stroke [39].

An interesting study compared the COX-gene sequence of patients with recurrent stroke (at least with two episodes) on aspirin and healthy subjects. The study found fourteen SNPs, and half of these lead to amino-acid substitutions; how-ever, none of these variations was located near the COX catalytic site, thus this genetic polymorphisms could not explain the failure to respond to aspirin in this population of stroke patients [40].

3.5.2. Clopidogrel. Clopidogrel is an oral, thienopyridine antiplatelet drug that irreversibly inhibits the P2Y12 subtype of ADP receptor, which has a major role in platelet aggregation. Clopidogrel has proven to be less effective in carriers of CYP2C19-reduced function allele $[37,38,66]$. These data have been confirmed in a recent meta-analysis that pooled 9 randomised trails for acute coronary syndrome or percutaneous coronary intervention; either homozygosis or heterozygosis carriers experience higher risk of stroke (Table 4) [35]. This could be caused by a relative reduction in the active metabolite of the drug, or by an insufficient inhibition of platelet aggregation. At a clinical level, CYP2C19 allele carriers have major adverse cardiovascular events, including stroke [35]. The TRITON TIMI 38 study on patients with acute coronary syndrome treated with PCI following clopidogrel versus another thienopyridine, "prasugrel," explored the role of ABCB1, a glycoprotein that might affect clopidog rel transport and metabolism. The polymorphism on ABCB1 $3435 \mathrm{C} \rightarrow$ T was correlated to a significant increase in adverse outcome including cardiovascular death, $\mathrm{MI}$, or stroke $(P=$ 0.0064). Specifically, TT homozygote patients had a $72 \%$ increased risk of the primary endpoint compared with CT/CC individuals [36]. This result might be a consequence of the absolute reduction in maximum platelet aggregation that has been evidenced in healthy subjects enrolled in the same study [36]. Furthermore, the PLATO study explored the same polymorphisms in noncoronary artery bypass graft patients on clopidogrel versus ticagrelor, a novel ADP receptor blocker that does not need hepatic activation, and so is not influenced by CYP2C19 alleles. Patients on ticagrelor were less likely to experience stroke independently of CYP2C19 or ABCB1 genotype. In addition, no specific genotype-drug interaction was associated with any major bleeding risk [37]. Finally, an important GWA study has been performed on a healthy Amish population and found a positive association with clopidogrel response measured by ADP platelet aggregation percentage and 10q24 region (Table 4). This region contains CYP2C19 * 2 genotype, which accounts for approximately $12 \%$ of the variation in clopidogrel response [38]. In addition, this study found a relevant association between this $\mathrm{CYP} 2 \mathrm{C} 19 * 2$ variant and event-free survival of adverse cardiovascular outcome in an independent population of 227 patients that underwent percutaneous coronary intervention [38].

\section{Conclusions}

Pharmacogenetics of stroke is a promising approach for optimizing treatment strategies aimed at decreasing stroke incidence and recurrence. Many candidate gene studies have examined the roles of polymorphisms on stroke treatment, and some of these have been replicated in GWA studies. However, few studies have considered stroke as an independent outcome, probably due to the relatively small number of events in the trails.

Antihypertensive agents are the most extensively studied drug class. Some polymorphisms have been consistently identified but results remain controversial, probably due to differences in study designs and methods, small sample sizes, and short durations of follow-up [67].

Statins and stroke have failed to find any interaction with most of the studied polymorphism. In addition, GWAs that consider stroke as an outcome are not available.

Tissue plasminogen activator has been investigated only in small studies on acute intravenous thrombolysis; thus, the pharmacogenetic data need to be reproduced in larger trails, and GWAs should be planned on humans in order to move forward in this field. Interestingly, a GWA study on ischemic rats has shown the genes regulated by rTPA treatment where different from the ones involved in ischemic stroke. In addition, gene expression profiles differed when reperfusion was or was not achieved [68]. If these results 
were to be replicated on humans, blood plasma could be used to monitor gene expression profiles, which are diversely associated with stroke and rtPA vessel recanalisation.

Anticoagulants dose variability has been consistently reported to be explained by CYP2C9 and VKORC1 for the 33\% and up to the 58\% when adding clinical information [69]. For this reason, the United States Food and Drug Administration suggests testing for these two polymorphisms in order to achieve stable dose and to avoid major hemorrhagic events. Although the pharmacogenetic approach on warfarin is feasible in clinical practice [70]; its use in improving outcome (i.e., shorter time to achieve range INR, more stable dosing, greater percentage of time in therapeutic range, and lesser major bleeding events) over the classical clinical approach has been proven in only small samples [71, 72]; for this reason, larger studies (GIFT, COAG, and EU-PACT) are ongoing to demonstrate the usefulness of the genetic approach and clinical algorithms (see www.clinicaltrials.gov/) on outcome improvement. Unfortunately, genotype-guided warfarin dosing has not been demonstrated to be cost effective [73]. Finally, in the near future, vitamin $\mathrm{K}$ antagonists could be gradually replaced in many indications with the newer anticoagulants (e.g., Dabigatran, Apixaban, and Rivaroxaban), which do not require monitoring and dose adjustment [74-76].

Antiaggregants: genetic studies on aspirin failure in recurrent stroke patients have been unsuccessful in finding their genetic determinant. Several polymorphisms have been linked to poor clinical response to clopidogrel, but to date, no study has proven the usefulness of the pharmacogenetic approach with clopidogrel in improving outcome. For this reason, the ACCF/AHA [77] disagreed with the FDA regarding their decision to add a warning on clopidogrel label recommending genetic testing when prescribing it for the first time. However, several studies, focusing on coronary disease, not on stroke, are ongoing: GeCCO, RAPID GENE, TARGET PCI, and GIANT (see http://www.clinicaltrials.gov/).

The future availability and low cost of technology will allow for the screening of a large number of genetic determinants. This will lead to the description of polymorphisms that affect drug pharmacokinetics and dynamics in each given patient. Furthermore, this information will optimize the efficacy/toxicity ratio. Although promising, the results of pharmacogenetic studies need to be confirmed in prospective randomised trials of comparative effectiveness, comparing the classical clinical and the genotype-guided approach, before being used in clinical settings. Furthermore, no study has explored yet the clinical usefulness of the genetic approach in reducing adverse events. For these reasons, although promising, the genotype-guided approach for drug prescriptions is not routinely recommended [56].

\section{Acknowledgments}

The authors would like to gratefully thank Dr. Stephanie Anne-Carine Debette and an unknown reviewer for critical revision of the manuscript, as well as Thomas Kilcline for writing assistance.

\section{References}

[1] K. L. Furie, S. E. Kasner, R. J. Adams et al., "Guidelines for the prevention of stroke in patients with stroke or transient ischemic attack: a guideline for healthcare professionals from the american heart association/american stroke association," Stroke, vol. 42, no. 1, pp. 227-276, 2010.

[2] L. B. Goldstein, C. D. Bushnell, R. J. Adams et al., "Guidelines for the primary prevention of stroke: a guideline for healthcare professionals from the American Heart Association/American Stroke Association," Stroke, vol. 42, no. 2, pp. 517-584, 2010.

[3] E. Floßmann, U. G. R. Schulz, and P. M. Rothwell, "Systematic review of methods and results of studies of the genetic epidemiology of ischemic stroke," Stroke, vol. 35, no. 1, pp. 212-227, 2004.

[4] M. J. E. Van Rijn, C. M. Van Duijn, and A. J. C. Slooter, "The impact of genetic testing on complex diseases," European Journal of Epidemiology, vol. 20, no. 5, pp. 383-388, 2005.

[5] W. E. Evans and H. L. McLeod, "Pharmacogenomics-drug disposition, drug targets, and side effects," The New England Journal of Medicine, vol. 348, no. 6, pp. 538-549, 2003.

[6] K. A. Phillips, D. L. Veenstra, E. Oren, J. K. Lee, and W. Sadee, "Potential role of pharmacogenomics in reducing adverse drug reactions: a systematic review," JAMA, vol. 286, no. 18, pp. 2270-2279, 2001.

[7] R. Weinshilboum, "Inheritance and drug response," The New England Journal of Medicine, vol. 348, no. 6, pp. 529-537, 2003.

[8] M. T. Lobmeyer, L. Wang, I. Zineh et al., "Polymorphisms in genes coding for GRK2 and GRK5 and response differences in antihypertensive-treated patients," Pharmacogenetics and Genomics, vol. 21, no. 1, pp. 42-49, 2011.

[9] A. L. Beitelshees, Y. Gong, D. Wang et al., "KCNMB1 genotype influences response to verapamil SR and adverse outcomes in the INternational VErapamil SR/Trandolapril STudy (INVEST)," Pharmacogenetics and Genomics, vol. 17, no. 9, pp. 719-729, 2007.

[10] B. G. Nordestgaard, K. Kontula, M. Benn et al., "Effect of ACE insertion/deletion and 12 other polymorphisms on clinical outcomes and response to treatment in the LIFE study," Pharmacogenetics and Genomics, vol. 20, no. 2, pp. 77-85, 2010.

[11] D. K. Arnett, B. R. Davis, C. E. Ford et al., "Pharmacogenetic association of the angiotensin-converting enzyme insertion/deletion polymorphism on blood pressure and cardiovascular risk in relation to antihypertensive treatment: the Genetics of Hypertension-Associated Treatment (GenHAT) study," Circulation, vol. 111, no. 25, pp. 3374-3383, 2005.

[12] A. I. Lynch, E. Boerwinkle, B. R. Davis et al., "Pharmacogenetic association of the NPPA T2238C genetic variant with cardiovascular disease outcomes in patients with hypertension," JAMA, vol. 299, no. 3, pp. 296-307, 2008.

[13] A. I. Lynch, E. Boerwinkle, B. R. Davis et al., "Antihypertensive pharmacogenetic effect of fibrinogen-beta variant-455G $>A$ on cardiovascular disease, end-stage renal disease, and mortality: the GenHAT study," Pharmacogenetics and Genomics, vol. 19, no. 6, pp. 415-421, 2009.

[14] R. N. Lemaitre, S. R. Heckbert, N. Sotoodehnia et al., " $\beta 1$ - and $\beta 2$-adrenergic receptor gene variation, $\beta$-blocker use and risk of myocardial infarction and stroke," American Journal of Hypertension, vol. 21, no. 3, pp. 290-296, 2008.

[15] H. Schelleman, O. H. Klungel, J. C. M. Witteman et al., "Angiotensinogen M235T polymorphism and the risk of myocardial infarction and stroke among hypertensive patients on ACEinhibitors or $\beta$-blockers," European Journal of Human Genetics, vol. 15, no. 4, pp. 478-484, 2007. 
[16] H. Schelleman, O. H. Klungel, J. C. M. Witteman et al., "Interaction between polymorphisms in the renin-angiotensin-system and angiotensin-converting enzyme inhibitor or $\beta$ blocker use and the risk of myocardial infarction and stroke," Pharmacogenomics Journal, vol. 8, no. 6, pp. 400-407, 2008.

[17] M. A. Pacanowski, Y. Gong, R. M. Cooper-DeHoff et al., “ $\beta$ adrenergic receptor gene polymorphisms and $\beta$-blocker treatment outcomes in hypertension," Clinical Pharmacology and Therapeutics, vol. 84, no. 6, pp. 715-721, 2008.

[18] M. A. Pacanowski, I. Zineh, R. M. Cooper-Dehoff, C. J. Pepine, and J. A. Johnson, "Genetic and pharmacogenetic associations between NOS3 polymorphisms, blood pressure, and cardiovascular events in hypertension," American Journal of Hypertension, vol. 22, no. 7, pp. 748-753, 2009.

[19] B. M. Psaty, N. L. Smith, S. R. Heckbert et al., "Diuretic therapy, the $\alpha$-adducin gene variant, and the risk of myocardial infarction or stroke in persons with treated hypertension," JAMA, vol. 287, no. 13, pp. 1680-1689, 2002.

[20] T. Gerhard, Y. Gong, A. L. Beitelshees et al., " $\alpha$-Adducin polymorphism associated with increased risk of adverse cardiovascular outcomes: results from GENEtic Substudy of the INternational VErapamil SR-trandolapril STudy (INVESTGENES)," American Heart Journal, vol. 156, no. 2, pp. 397404, 2008.

[21] S. B. Harrap, C. Tzourio, F. Cambien et al., "The ACE gene I/D polymorphism is not associated with the blood pressure and cardiovascular benefits of ACE inhibition," Hypertension, vol. 42, no. 3, pp. 297-303, 2003.

[22] L. A. Hindorff, R. N. Lemaitre, N. L. Smith et al., "Common genetic variation in six lipid-related and statin-related genes, statin use and risk of incident nonfatal myocardial infarction and stroke," Pharmacogenetics and Genomics, vol. 18, no. 8, pp. 677-682, 2008.

[23] J. C. Hopewell, S. Parish, R. Clarke et al., "No impact of KIF6 Genotype on vascular risk and statin response among 18,348 randomized patients in the heart protection study," Journal of the American College of Cardiology, vol. 57, no. 20, pp. 20002007, 2011.

[24] A. H. Maitland-van der Zee, B. H. C. Stricker, O. H. Klungel et al., "The effectiveness of hydroxy-methylglutaryl coenzyme A reductase inhibitors (statins) in the elderly is not influenced by apolipoprotein E genotype," Pharmacogenetics, vol. 12, no. 8, pp. 647-653, 2002.

[25] A. H. Maitland-van der Zee, E. Boerwinkle, D. K. Arnett et al., "Absence of an interaction between the angiotensinconverting enzyme insertion-deletion polymorphism and pravastatin on cardiovascular disease in high-risk hypertensive patients: the Genetics of Hypertension-Associated Treatment (GenHAT) study," American Heart Journal, vol. 153, no. 1, pp. 54-58, 2007.

[26] J. Broderick, M. Lu, C. Jackson et al., "Apolipoprotein E phenotype and the efficacy of intravenous tissue plasminogen activator in acute ischemic stroke," Annals of Neurology, vol. 49, no. 6, pp. 736-744, 2001.

[27] I. Fernández-Cadenas, J. Álvarez-Sabín, C. A. Molina et al., "ApoE genotype influences on efficacy and safety of thrombolytic treatment for ischemic stroke," Neurologia, vol. 21, no. 4, pp. 176-180, 2006.

[28] A. D. del Río-Espínola, I. Fernández-Cadenas, M. Rubiera et al., "CD40-1C>T polymorphism ( $\mathrm{rs} 1883832$ ) is associated with brain vessel reocclusion after fibrinolysis in ischemic stroke," Pharmacogenomics, vol. 11, no. 6, pp. 763-772, 2010.
[29] I. Fernández-Cadenas, C. A. Molina, J. Álvarez-Sabín et al., "ACE gene polymorphisms influence t-PA-induced brain vessel reopening following ischemic stroke," Neuroscience Letters, vol. 398, no. 3, pp. 167-171, 2006.

[30] I. Fernandez-Cadenas, J. Alvarez-Sabin, M. Ribo et al., "Influence of thrombin-activatable fibrinolysis inhibitor and plasminogen activator inhibitor-1 gene polymorphisms on tissuetype plasminogen activator-induced recanalization in ischemic stroke patients," Journal of Thrombosis and Haemostasis, vol. 5, no. 9, pp. 1862-1868, 2007.

[31] R. González-Conejero, I. Fernández-Cadenas, J. A. Iniesta et al., "Role of fibrinogen levels and factor XIII V34L polymorphism in thrombolytic therapy in stroke patients," Stroke, vol. 37, no. 9, pp. 2288-2293, 2006.

[32] J. Montaner, I. Fernández-Cadenas, C. A. Molina et al., "Safety profile of tissue plasminogen activator treatment among stroke patients carrying a common polymorphism (C-1562T) in the promoter region of the matrix metalloproteinase- 9 gene," Stroke, vol. 34, no. 12, pp. 2851-2855, 2003.

[33] M. L. Arnold, C. Grond-Ginsbach, M. Kloss et al., "Pharmacogenetic testing for guiding de novo phenprocoumon therapy in stroke patients," Cerebrovascular Diseases, vol. 28, no. 5, pp. 468-471, 2009.

[34] R. Kimura, K. Miyashita, Y. Kokubo et al., "Genotypes of vitamin $\mathrm{K}$ epoxide reductase, $\gamma$-glutamyl carboxylase, and cytochrome P450 2C9 as determinants of daily warfarin dose in Japanese patients," Thrombosis Research, vol. 120, no. 2, pp. 181-186, 2007.

[35] J. L. Mega, T. Simon, J. P. Collet et al., "Reduced-function CYP2C19 genotype and risk of adverse clinical outcomes among patients treated with clopidogrel predominantly for PCI: a meta-analysis," JAMA, vol. 304, no. 16, pp. 1821-1830, 2010.

[36] J. L. Mega, S. L. Close, S. D. Wiviott et al., "Genetic variants in ABCB1 and CYP2C19 and cardiovascular outcomes after treatment with clopidogrel and prasugrel in the TRITONTIMI 38 trial: a pharmacogenetic analysis," The Lancet, vol. 376, no. 9749, pp. 1312-1319, 2010.

[37] L. Wallentin, S. James, R. F. Storey et al., "Effect of CYP2C19 and $\mathrm{ABCB} 1$ single nucleotide polymorphisms on outcomes of treatment with ticagrelor versus clopidogrel for acute coronary syndromes: a genetic substudy of the PLATO trial," The Lancet, vol. 376, no. 9749, pp. 1320-1328, 2010.

[38] A. R. Shuldiner, J. R. O’Connell, K. P. Bliden et al., "Association of cytochrome P450 2C19 genotype with the antiplatelet effect and clinical efficacy of clopidogrel therapy," JAMA, vol. 302, no. 8, pp. 849-858, 2009.

[39] N. Clappers, M. G. H. Van Oijen, S. Sundaresan et al., "The C50T polymorphism of the cyclooxygenase-1 gene and the risk of thrombotic events during low-dose therapy with acetyl salicylic acid," Thrombosis and Haemostasis, vol. 100, no. 1, pp. 70-75, 2008.

[40] A. Hillarp, B. Palmqvist, S. Lethagen, B. O. Villoutreix, and I. Mattiasson, "Mutations within the cyclooxygenase-1 gene in aspirin non-responders with recurrence of stroke," Thrombosis Research, vol. 112, no. 5-6, pp. 275-283, 2004.

[41] G. A. Donnan, S. M. Davis, and A. Thrift, "The role of blood pressure lowering before and after stroke," Current Opinion in Neurology, vol. 16, no. 1, pp. 81-86, 2003.

[42] P. Manunta, L. Citterio, C. Lanzani, and M. Ferrandi, "Adducin polymorphisms and the treatment of hypertension," Pharmacogenomics, vol. 8, no. 5, pp. 465-472, 2007. 
[43] U. Förstermann and T. Münzel, "Endothelial nitric oxide synthase in vascular disease: from marvel to menace," Circulation, vol. 113, no. 13, pp. 1708-1714, 2006.

[44] S. D. S. Maggo, M. A. Kennedy, and D. W. J. Clark, "Clinical implications of pharmacogenetic variation on the effects of statins," Drug Safety, vol. 34, no. 1, pp. 1-19, 2011.

[45] H. Elghannam, S. Tavackoli, L. Ferlic, A. M. Gotto, C. M. Ballantyne, and A. J. Marian, "A prospective study of genetic markers of susceptibility to infection and inflammation, and the severity, progression, and regression of coronary atherosclerosis and its response to therapy," Journal of Molecular Medicine, vol. 78, no. 10, pp. 562-568, 2000.

[46] O. A. Iakoubova, M. S. Sabatine, C. M. Rowland et al., "Polymorphism in KIF6 gene and benefit from statins after acute coronary syndromes: results from the PROVE IT-TIMI 22 study," Journal of the American College of Cardiology, vol. 51, no. 4, pp. 449-455, 2008.

[47] E. Bluhmki, Á. Chamorro, A. Dávalos et al., "Stroke treatment with alteplase given $3 \cdot 0-4 \cdot 5 \mathrm{~h}$ after onset of acute ischaemic stroke (ECASS III): additional outcomes and subgroup analysis of a randomised controlled trial," The Lancet Neurology, vol. 8, no. 12, pp. 1095-1102, 2009.

[48] J. R. Marler, "Tissue plasminogen activator for acute ischemic stroke," The New England Journal of Medicine, vol. 333, no. 24, pp. 1581-1587, 1995.

[49] R. Dubinsky and S. M. Lai, "Mortality of stroke patients treated with thrombolysis: analysis of nationwide inpatient sample," Neurology, vol. 66, no. 11, pp. 1742-1744, 2006.

[50] C. A. Molina, J. Montaner, J. F. Arenillas, M. Ribo, M. Rubiera, and J. Alvarez-Sabín, "Differential pattern of tissue plasminogen activator-induced proximal middle cerebral artery recanalization among stroke subtypes," Stroke, vol. 35, no. 2, pp. 486-490, 2004.

[51] J. M. Wardlaw, C. P. Warlow, and C. Counsell, "Systematic review of evidence on thrombolytic therapy for acute ischaemic stroke," The Lancet, vol. 350, no. 9078, pp. 607-614, 1997.

[52] J. J. Sheehan and S. E. Tsirka, "Fibrin-modifying serine proteases thrombin, tPA, and plasmin in ischemic stroke: a review," Glia, vol. 50, no. 4, pp. 340-350, 2005.

[53] P. Ladenvall, S. Nilsson, K. Jood, A. Rosengren, C. Blomstrand, and C. Jern, "Genetic variation at the human tissue-type plasminogen activator (tPA) locus: haplotypes and analysis of association to plasma levels of tPA," European Journal of Human Genetics, vol. 11, no. 8, pp. 603-610, 2003.

[54] A. J. Grau and C. Lichy, "Stroke and the CD40-CD40 ligand system: at the hinge between inflammation and thrombosis," Stroke, vol. 34, no. 6, pp. 1417-1418, 2003.

[55] A. Farzaneh-Far, J. D. Davies, L. A. Braam et al., "A polymorphism of the human matrix gamma-carboxyglutamic acid protein promoter alters binding of an activating protein-1 complex and is associated with altered transcription and serum levels," The Journal of Biological Chemistry, vol. 276, no. 35, pp. 32466-32473, 2001.

[56] L. Wang, H. L. McLeod, and R. M. Weinshilboum, "Genomics and drug response," The New England Journal of Medicine, vol. 364, no. 12, pp. 1144-1153, 2011.

[57] M. M. Donohue and D. L. Tirschwell, "Implications of pharmacogenetic testing for patients taking warfarin or clopidogrel," Current Neurology and Neuroscience Reports, vol. 11, no. 1, pp. 52-60, 2011.

[58] G. P. Aithal, C. P. Day, P. J. L. Kesteven, and A. K. Daly, "Association of polymorphisms in the cytochrome P450 CYP2C9 with warfarin dose requirement and risk of bleeding complications," The Lancet, vol. 353, no. 9154, pp. 717-719, 1999.
[59] M. J. Rieder, A. P. Reiner, B. F. Gage et al., "Effect of VKORC1 haplotypes on transcriptional regulation and warfarin dose," The New England Journal of Medicine, vol. 352, no. 22, pp. 2285-2293, 2005.

[60] P. H. Reitsma, J. F. Van Der Heijden, A. P. Groot, F. R. Rosendaal, and H. R. Büller, "A C1173T dimorphism in the VKORC1 gene determines coumarin sensitivity and bleeding risk," PLoS Medicine, vol. 2, no. 10, article e312, 2005.

[61] E. Stepień, A. Branicka, M. Cieśla-Dul, and A. Undas, "A vitamin $\mathrm{K}$ epoxide reductase-oxidase complex gene polymorphism $(-1639 \mathrm{G}>\mathrm{A})$ and interindividual variability in the doseeffect of vitamin K antagonists," Journal of Applied Genetics, vol. 50, no. 4, pp. 399-403, 2009.

[62] F. Takeuchi, R. McGinnis, S. Bourgeois et al., "A genome-wide association study confirms VKORC1, CYP2C9, and CYP4F2 as principal genetic determinants of warfarin dose," PLoS Genetics, vol. 5, no. 3, Article ID e1000433, 2009.

[63] M. Teichert, M. Eijgelsheim, F. Rivadeneira et al., "A genomewide association study of acenocoumarol maintenance dosage," Human Molecular Genetics, vol. 18, no. 19, pp. 37583768, 2009.

[64] C. Pettinella, M. Romano, L. Stuppia, F. Santilli, R. Liani, and G. Davì, "Cyclooxygenase-I haplotype C50T/A-842G does not affect platelet response to aspirin," Thrombosis and Haemostasis, vol. 101, no. 4, pp. 687-690, 2009.

[65] R. Gonzalez-Conejero, J. Rivera, J. Corral, C. Acuña, J. A. Guerrero, and V. Vicente, "Biological assessment of aspirin efficacy on healthy individuals: heterogeneous response or aspirin failure?" Stroke, vol. 36, no. 2, pp. 276-280, 2005.

[66] M. J. Sorich, A. Vitry, M. B. Ward, J. D. Horowitz, and R. A. Mckinnon, "Prasugrel vs. clopidogrel for cytochrome P450 2C19-genotyped subgroups: integration of the TRITON-TIMI 38 trial data," Journal of Thrombosis and Haemostasis, vol. 8, no. 8, pp. 1678-1684, 2010.

[67] D. K. Arnett and S. A. Claas, "Pharmacogenetics of antihypertensive treatment: detailing disciplinary dissonance," Pharmacogenomics, vol. 10, no. 8, pp. 1295-1307, 2009.

[68] G. C. Jickling, X. Zhan, B. P. Ander et al., "Genome response to tissue plasminogen activator in experimental ischemic stroke," BMC Genomics, vol. 11, no. 1, article 254, 2010.

[69] P. Lenzini, M. Wadelius, S. Kimmel et al., "Integration of genetic, clinical, and INR data to refine warfarin dosing," Clinical Pharmacology and Therapeutics, vol. 87, no. 5, pp. 572$578,2010$.

[70] M. A. Hillman, R. A. Wilke, S. H. Yale et al., "A prospective, randomized pilot trial of model-based warfarin dose initiation using CYP2C9 genotype and clinical data," Clinical Medicine \& Research, vol. 3, no. 3, pp. 137-145, 2005.

[71] J. L. Anderson, C. D. Adams, E. M. Antman et al., "ACC/AHA 2007 guidelines for the management of patients with unstable angina/non ST-elevation myocardial infarction: a report of the American College of Cardiology/American Heart Association Task Force on Practice Guidelines (Writing Committee to Revise the 2002 Guidelines for the Management of Patients With Unstable Angina/Non ST-Elevation Myocardial Infarction): developed in collaboration with," Circulation, vol. 116, no. 7, pp. e148-e304, 2007.

[72] Y. Caraco, S. Blotnick, and M. Muszkat, "CYP2C9 genotypeguided warfarin prescribing enhances the efficacy and safety of anticoagulation: a prospective randomized controlled study," Clinical Pharmacology and Therapeutics, vol. 83, no. 3, pp. 460-470, 2008.

[73] M. H. Eckman, J. Rosand, S. M. Greenberg, and B. F. Gage, "Cost-effectiveness of using pharmacogenetic information in 
warfarin dosing for patients with nonvalvular atrial fibrillation," Annals of Internal Medicine, vol. 150, no. 2, pp. 73-83, 2009.

[74] "Rivaroxaban-once daily, oral, direct factor Xa inhibition compared with vitamin $\mathrm{K}$ antagonism for prevention of stroke and Embolism Trial in Atrial Fibrillation: rationale and design of the ROCKET AF study," American Heart Journal, vol. 159, no. 3, pp. 340-347, 2010.

[75] S. J. Connolly, J. Eikelboom, C. Joyner et al., "Apixaban in patients with atrial fibrillation," The New England Journal of Medicine, vol. 364, no. 9, pp. 806-817, 2011.

[76] S. J. Connolly, M. D. Ezekowitz, S. Yusuf et al., "Dabigatran versus warfarin in patients with atrial fibrillation," The New England Journal of Medicine, vol. 361, no. 12, pp. 1139-1151, 2009.

[77] D. R. Holmes Jr., G. J. Dehmer, S. Kaul, D. Leifer, P. T. O'Gara, and C. M. Stein, "ACCF/AHA clopidogrel clinical alert: approaches to the FDA "boxed warning": a report of the American college of cardiology foundation task force on clinical expert consensus documents and the American heart association," Journal of the American College of Cardiology, vol. 56, no. 4, pp. 321-341, 2010. 


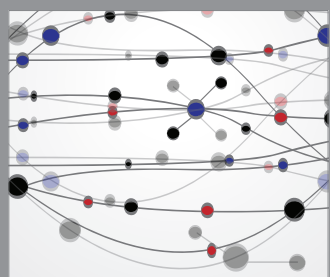

The Scientific World Journal
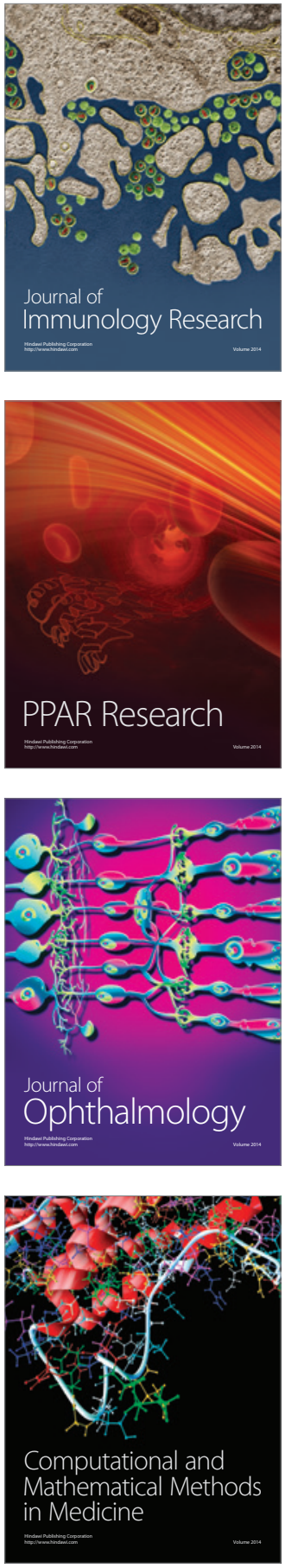

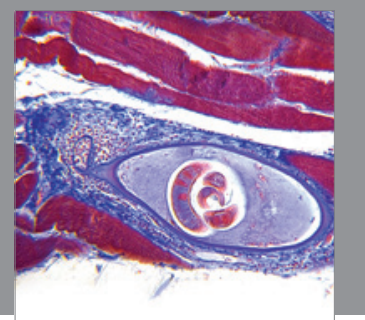

Gastroenterology

Research and Practice
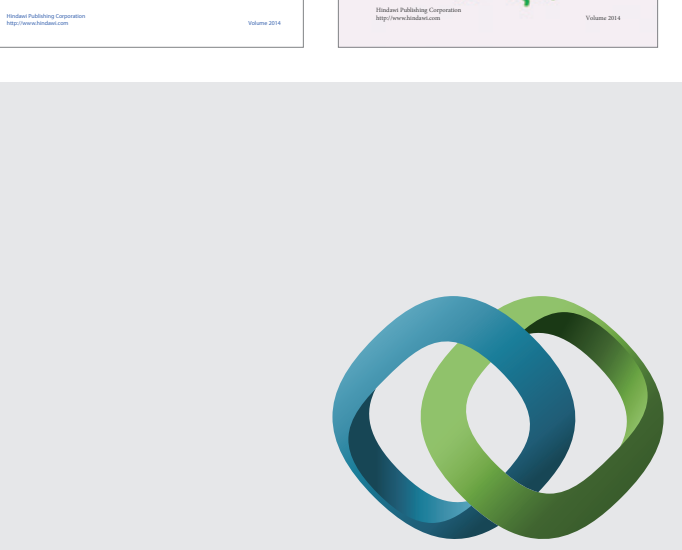

\section{Hindawi}

Submit your manuscripts at

http://www.hindawi.com
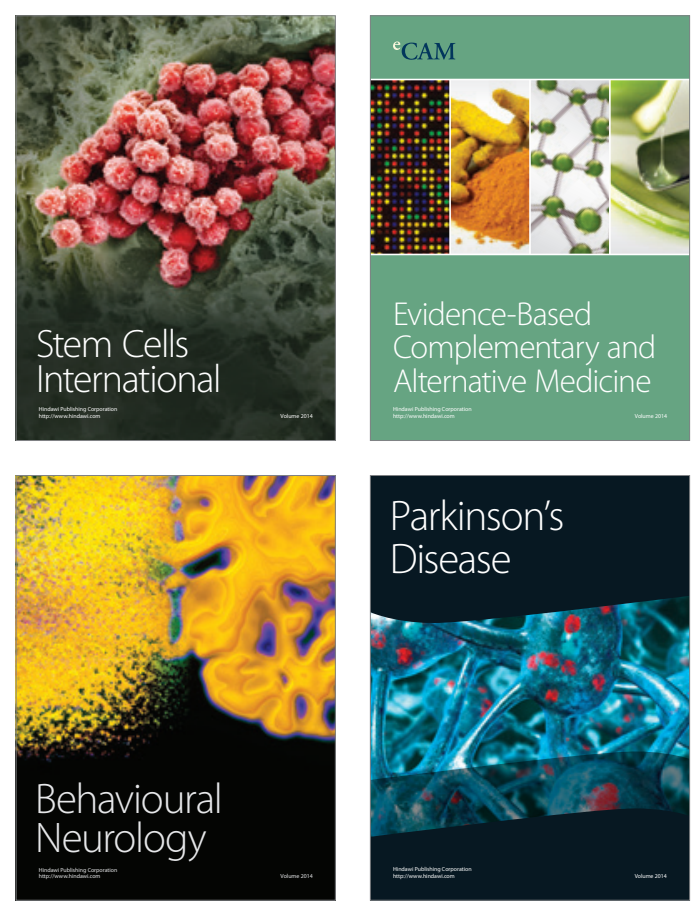

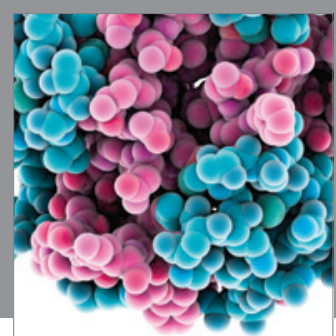

Journal of
Diabetes Research

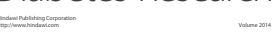

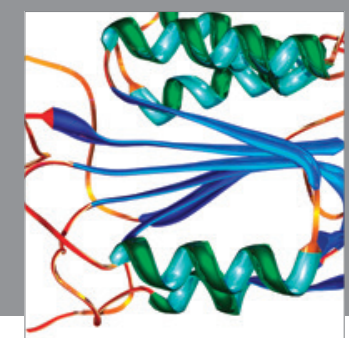

Disease Markers
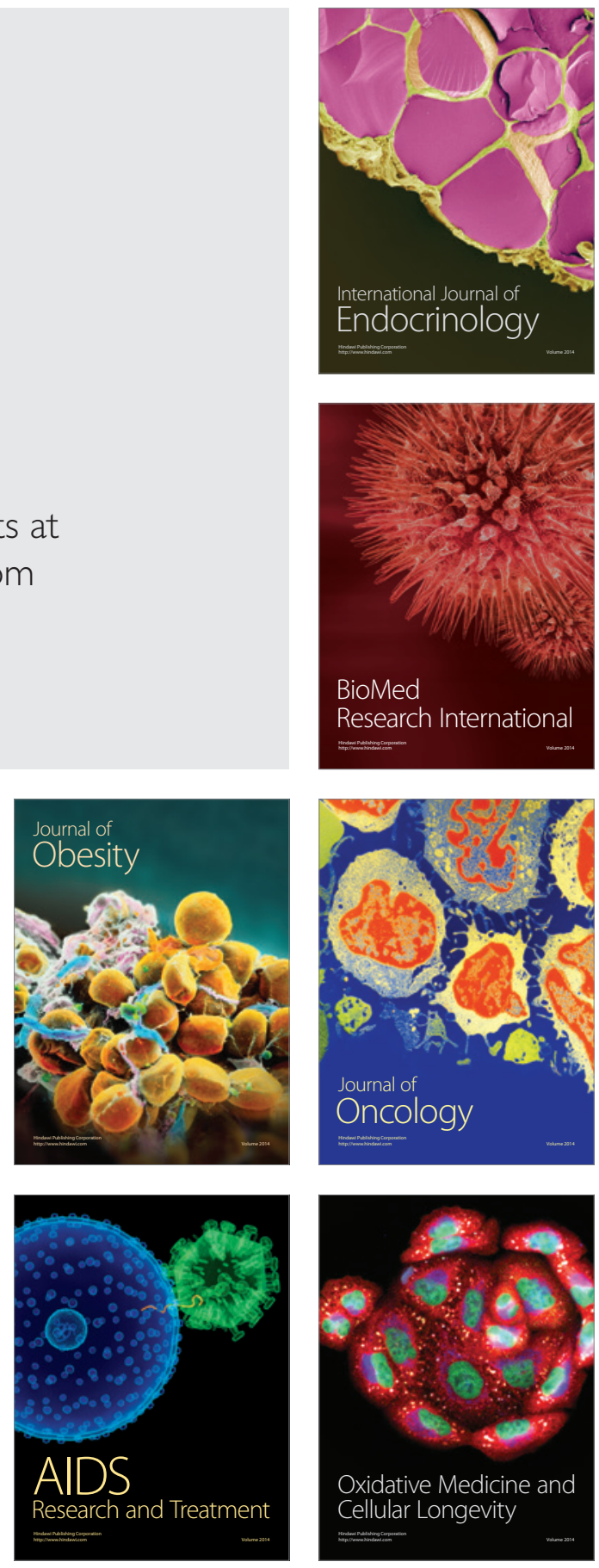